\title{
KANSAlAistUTKIMUS: TOISENLAISTA TUTKIMUSTA
}

Briitta Koskiaho: YTT, professori (emerita), Tampereen yliopisto

brïtta.koskiaho@tuni.fi

Janus vol. 27 (1) 2019, 72-78

Kansalaistutkimus, englanniksi citizen science, ruotsiksi medborgarforskning ja saksaksi die Bürgerwissenschaft, on tutkimusta, jossa tieteelliseen tutkimukseen, sen tekijöiksi, otetaan ammattitutkijoiden kanssa työtä tekemään maallikoita. Useimmiten kansalaistutkimusta on käytetty ja käytetään yhä luonnontieteellisessä ja teknistieteellisessä tutkimuksessa. Vanhimpia kansalaistutkijoiden alueita on ollut arkeologisiin kaivauksiin osallistuminen. Ympäristötutkimuksessa lintubongarit tai muun luonnon havainnoitsijat ovat voineet muodostaa havaintojen teon ketjuja, joita sitten ammattitutkijat ovat käyttäneet hyväkseen. Viime aikoina on myös kansanterveystieteellisissä projekteissa käytetty kansalaistutkijoita hyväksi muun muassa haastattelemassa oman alueensa muita asukkaita, jotta alueen asukkaitten terveystilannetta voidaan kartoittaa köyhillä asuinalueilla esimerkiksi Britanniassa.

\section{KANSALAISTUTKIMUKSEN LUONNE}

Saksalainen, ministeriön kanssa yhteistyötä tekevä, kansalaistutkimuksen alustan tutkijaryhmä on sijoittanut tämän tutkimuksen kolmelle tasolle (Grünbuch Citizen Science Strategie 2020 für Deutschland 2017).
Kansalaistutkimus voi olla luonteeltaan sellaista, jossa kansalaiset työskentelevät täysin palkein ammattitutkijoiden rinnalla ja kanssa. Usein kysymys on tietyistä vaiheista tutkimusprosessia, kuten aineiston kerääminen ja tulosten analysointi ja/tai johtopäätösten tekeminen. Jos on kysymys kehittämistutkimuksesta, jossa päädytään käytännön toimenpiteiden suosittamiseen, kansalaistutkijoiden panos voi olla tärkeä lopputuloksen kannalta.

Toinen vaihtoehto on, että kansalaiset tekevät kysymyksiä ja johdattelevat tutkijat kansalaisten kannalta katsoen "oikealle tielle" ajattelutavassaan ja tutkimuskysymysten teossa. Kansalaiset ovat aktiivisia osallistujia.

Kolmas vaihtoehto sisältää kansalaisten kannalta ulkopuolista vaikuttamista tutkimukseen. Roolina on passiivisen tarkkailijan rooli. Kansalaiset esittävät ideoitaan tutkimuskysymyksestä mutta myös esimerkiksi empiirisen tutkimuksen teosta, paikasta ja tavasta.

Eurooppalainen kansalaistutkijoiden järjestö, The European Citizen Science Association ESCA, esittää seuraavia ehtoja kansalaistutkimukselle (ks. https:// ecsa.citizen-science.net/):

- $\quad$ kansalaisten tulee saada tietää, mitä heidän kontribuutiolleen tapahtuu 
- tutkimuksessa pitää saada oikeita tieteellisiä tuloksia eli se on "oikeata" tutkimusta

- kansalaisten panoksen tulee olla näkyvillä, se on havaittu ja tunnustettu

- prosessin tulee olla arvioitavissa niin, että voimme oppia, mikä toimii.

Brittien ympäristötutkimuksellisen kansalaistutkimuksen luonnetta ja ehtoja analysoineessa raportissa kiinnitetään huomiota kansalaistutkijoiden motivaatioon ja tietojen välittämiseen (Geoghegan ym. 2016). Kansalaistutkijoiden mukana pysymiseen vaikuttaa suuresti se, miten heidän kanssaan kommunikoidaan ja pidetään yhteyttä. Yhteydenpidon tulee olla tiivistä, jotta osallisten mielenkiinto ei herpaannu (West \& Pateman 2016).

Kansalaistiede ei ole vain vapautta vaan myös vastuullista toimintaa. Osallistuminen vaatii taitoja havainnoida ja analysoida tietoa, vaikka ei vaaditakaan tieteellisten tutkimusmetodien käyttöä. Riippuen kansalaistieteen kohdetieteestä vaaditaan erilaisia emotieteelle ominaisia taitoja. Yleinen vaatimus on, että kansalaistieteessä vaaditaan digitaitoja, useimmiten tieto ja kommunikaatio siirtyvät internetiä tai älypuhelinta käyttäen koko prosessin ajan.

Usein kansalaistutkijat tekevät vapaaehtoistyötä mutta saattavat tutkimuksen rahoituksesta riippuen myös saada palkkioita. Motivaationa osallistumiseen toimii kuitenkin erityinen kiinnostus aiheeseen, halu saada aikaan muutosta käytäntöön ja idealismi. Tieto tutkimuksesta siirtyy myös tällä tavoin sujuvasti tutkimuspiirin ulkopuolelle.
Tällöin on kiinnitettävä huomiota eettisiin sääntöihin kuten arkaluontoisen tiedon luottamuksellisuuteen. Kansalaistutkijoista itsestään riippuu, missä määrin heidän kontribuutionsa tutkimuskokonaisuuteen ilmoitetaan ulkopuolisille.

Kansalaistiedettä ja -tutkimusta voidaan käsitellä samasta peruslähtökohdasta kuin tieteellisen tiedon hankkimista yleensä. Kysymys on uuden tiedon hankkimisesta ja maailman ymmärryksen avartamisesta. Tällöin toivotaan, että tutkimuksessa saatu tieto välittyy yhteiskunnan toimijoille ja muuttaa maailmaa sekä auttaa sen ymmärtämistä uudesta näkökulmasta. Tällöin kansalaistutkijoilla on asiantuntija-asema. Toinen tapa ymmärtää kansalaistutkimus on yhteisöllinen, kuten oppivan yhteisön ajatuksessa. Tällöin ajatellaan oppimisen muuttavan maailmaa, ainakin kyseessä olevaa yhteisöä. Kolmas tapa on ymmärtää kansalaistutkimus radikaalina aktivismina, keinona muuttaa maailmaa suoraan. Halutaan saada johonkin epäkohtaan nopeasti muutos (ks. White Paper on Citizen Science 2015).

\section{YhteiskUNTATIETEELLINEN KANSALAISTUTKIMUS}

Englanninkielessä käytetään käsitettä citizen social research yhteiskuntatieteellisestä tutkimuksesta, joka on kansalaistutkimusta. Siinä on ollut usein kysymys kansalaistutkijoiden oman elämän parantamispyrkimyksestä. Osallistumisen motivaation voi olettaa tulevan tätä kautta. Asiantuntijat taas ovat kehittämässä kansalaisten elämää parantavia järjestelmiä, joten he saavat 
informaatiota omaa työtään varten. Jos tutkimuksessa on kysymys vapaaehtoistyöstä, niin kansalaisten kuin asiantuntijatutkijoidenkin osalta, on tärkeätä ymmärtää, mikä yleensä motivoi ihmisiä osallistumaan vapaaehtoistoimintaan. Manchesterin yliopistossa Britanniassa on käynnissä vanhoihin ihmisiin kohdistuva tieteidenvälinen tutkimustoiminta, jossa pyritään saamaan eri organisaatioita ja vanhoja ihmisiä yhteistoimintaan tutkijoiden kanssa. Tämä lähestymistapa perustuu yhteiskuntatieteiden kykyyn saattaa eri osapuolet yhteen. Kysymys on kansalaistutkimuksen nostamisesta ensimmäiseltä tietojen keräämisen askeleelta seuraavaan, kollaboratiiviseen vaiheeseen (Manchester Institute for Collaborative Research on Ageing).

The League of European Research Universities toteaa, että kansalaistieteen ja -tutkimuksen avulla voidaan parantaa tutkimuksen laatua ja määrää, joten oikein tehtynä se on hyödyksi kaikille osapuolille ja maailmalle (Citizen Science at Universities: Trends, Guidelines and Recommendations 2016). Tämän mukaan kansalaistiede yliopistollisena tutkimuksena voidaan ymmärtää tiedon yhteistuotantona ja sen yhteisluomisena. Se on vapaata ja osallistavaa. Siinä tutkitaan asioita, jotka ovat lähellä kansalaisia ja laajaa yleisöä. Lähestymistapa on osallistava ja yhdessäluova eli positiivinen. Tarkoitus on hyödyntää uudella tiedolla myös instituutioita. Kansalaistiede luo myös haasteita vallitseville tutkimusinstituutioille. Tarkoituksena on, että se hyödyttää myös kansalaisia: tekee näistä aktiivisempia, vastuullisempia ja osallistuvampia. Tietoja ei pantata vaan niitä jaetaan yleisölle eli kaikille.
Urban Living Lab -nimikkeen alla on viime vuosina ideoitu kaupunginosa-alueita ja näiden palveluja. Siinä tarvitaan kansalaistieteen kaltaista lähestymistapaa, kun kansalaiset asukkaiden roolissa otetaan mukaan alueen kehittämiseen (Nesti 2018). Aiemmin puhuttiin toimintatutkimuksesta ja osallistavasta tutkimuksesta kaupunkisuunnitteluun liitettyinä. Nyt tässäkin yhteydessä puhutaan innovaatiopolitiikasta, jossa voidaan käyttää hyväksi kansalaistutkimuksellista lähestymistapaa ideanaan yhteistuotanto ja -luominen. Saadaan yhdessä aikaan jotain uutta ja konkreettista, kuten uutta urbaania ympäristöä ja toimintaa.

\section{ESIMERKKI YHTEISKUNTATIETEELLISESTÄ KANSALAISTUTKIMUKSESTA}

Esimerkki kansalaistutkimuksesta on yritys selvittää vanhojen ihmisten selviytymistä omien asioittensa ajamisesta nyky-yhteiskunnassa. Voidaan kysyä, miksi tarvitaan pohdintaa vanhojen ihmisten tai vammaisten selviytymisestä omassa yhteiskunnassaan ja omalla asuinpaikkakunnallaan. Vanhojen ikäluokkien syrjäytymisvaara on tämän hetken sosiaalinen ongelma tai osa sitä. Vanhenemisesta on tulossa ongelma yhteiskunnan erittäin nopean muutosvauhdin vuoksi.Yhteiskunnan muuttuessa ehdot, joiden mukaan yhteiskunnassa eletään, muuttuvat. Niinpä tällä hetkellä on syytä varmistaa, että ikääntyneet saavat asiansa ajettua, että heidän ongelmansa otetaan todesta ja niitä pyritään ratkaisemaan. Tähän toimintaan tarvitaan usein ulkopuolisia. Pelkkä omaehtoisuus ei riitä voimien hiipuessa, vaikka ei vielä oltaisi tilanteessa, jossa vanha ihminen tarvitsee edunvalvontaa 
tai jatkuvaa auttamista, jotta hänen sosiaaliset oikeutensa toteutuvat ja hän voi elää täyttä kansalaisuutta. Kansalaisten kyvystä selviytyä oikeuksiensa puolustamisesta ja velvollisuuksiensa täyttämisestä on tulossa sosiaalipoliittinen kysymys.

Vanhuus on prosessi kuten lapsuus ja nuoruuskin. Se ei pysy yhden ihmisen kohdalla samanlaisena kovin pitkään, vaikka ulkoiset elämisen puitteet säilyisivät ennallaan. Jos ne muuttuvat ratkaisevasti toisenlaisiksi kuin aiemmin tai jos ulkoisissa puitteissa on koko ajan muutosta, selviytyminen yhteiskunnassa on koko ajan lisääntyvien ponnistelujen varassa. Ponnistelua tarvitaan aina enemmän mitä vanhemmaksi tulee tai mitä nopeammin tai suuremmin ulkoiset puitteet muuttuvat. Tämä on paradoksaalista: voimat hiipuvat mutta vaatimukset selviytymisestä kasvavat!

Yhteiskuntamme edellyttää, että sen kansalaiset ovat aktiivisia ja osallisia. Vammaisten osalta on käyty ns. normaaliuskeskustelua jo vuosikymmenet. Kansalaisten osallistuminen yhteiskunnalliseen elämään on itsestäänselvyys. Sellaisten kansalaisten, joilla on fyysisiä, psyykkisiä, sosiaalisia tai kulttuurisia esteitä täysipainoiseen osallistumiseen, tulisi saada tukea, neuvoa ja opastusta. Oikeuksiensa ajamiseen he tarvitsisivat myös asioittensa ajajia, jotta he pystyisivät edes avusteiseen osallisuuteen yhteiskunnassaan. Näön heikkeneminen ja kuulon huononeminen tai lähimuistin alaspäin meno vaikuttavat rohkeuteen tarttua uusien asioiden oppimiseen kuten digimaailmassa mukana pysymiseen. Kun yhteiskunta digitalisoi enenevästi eri toimintojansa, on kansalaisten pysyttävä perässä ja hallittava uusia temppuja ja välineitä. Asioimisen digitalisoitumisen lisäksi varsinkin julkisten palvelujen monimutkaistumisen hallinta tuottaa hankaluuksia. Yhteiskunnan toimintoja uudistetaan koko ajan kiihtyvällä tahdilla ja nimet sekä niiden sisällöt vaihtuvat nopeasti. Henkilön, joka on työelämän ulkopuolella, on huomattavasti vaikeampaa pysyä ajan tasalla kuin sen sisällä olevan.

Kysymys kuuluu: Kenen velvollisuus on järjestää asioitten hoitamiseen liittyvää tukea? Onko se vanhojen ihmisten omalla vastuulla ehkä omaisten tukemana vai onko se yhteiskunnan virallisten organisaatioiden tehtävä kolmannen sektorin ja yksityisen kaupallisen sektorin avustaessa? Tällä hetkellä erilaiset neuvonta- ja opastuspalvelut ovat hyvin siiloutuneita ja toimivat kaukana asuinympäristöstä urbaaneilla alueilla. Maaseudulta ne taas voivat puuttua kokonaan.

Valtiovarainministeriö on viime vuosina kohdistanut huomionsa kahteen osa-alueeseen, jotka koskevat kansalaisten asemaa yhteiskunnassa. Toinen on palvelujen kehittäminen, joka liittyy myös sote-uudistukseen ja toinen kansalaisten osallisuus (esim. Julkisten palvelujen digitalisointihanke mukaan lukien AUTA-hanke 2016-2017 ja Digituen toimintamalliehdotus 2017). Molemmissa on kiinnitetty huomiota myös vanhojen ja vammaisten kansalaisuuteen sekä oikeuteen osallistua ja saada palveluita. Myös informaation saamiseen ja jakamiseen eri tavoin kiinnitetään huomiota. Tarkoitus on siirtyä julkisissa palveluissa digipalveluihin mitä suurimmassa määrin. Samaan aikaan myös yksityiset palvelut, esimer- 
kiksi pankkipalvelut, siirtyvät entistä enemmän mobiiliaikaan.

Mainittuja ryhmiä on tuettava, jotta niiden jäsenet yltävät täyteen kansalaisuuteen. Jos nimitämme tukemisprosessia asioiden ajamisprosessiksi, joka alkaa neuvoilla ja päätyy varsinaiseen avustamiseen, on pohdittava sitä, mitä on asiakkuus, asiakkaan asema, hänen oma kapasiteettinsa ja mahdollisuutensa vaikuttaa omiin asioihinsa. Kysymys on myös vallasta, asiakkaan voimaannuttamisesta mutta myös avustajan vallasta ja sen mahdollisesta muuttumisesta suhteessa avuttomuuden etenemiseen. Taustalla ovat käsitykset siitä, minkälaiseen yhteiskuntaan ollaan menossa.

Kansalaistutkimus "Ihan pihalla?" on tarkoittanut sitä, että asioittensa ajamistarpeessa olevat, useimmat 75 vuotta täyttäneitä, eri puolilla Suomea asuvat koulutetut henkilöt ovat koko tutkimusprosessissa (2018-2019) itse mukana. Kansalaistutkimuksen tarkoituksena on ollut 1) kartoittaa asioitten ajamisen avun tarpeen tilannetta 75-vuotta täyttäneiden koulutettujen eri puolilla Suomea asuvien kohdalla, 2) kartoittaa hankkeita, jotka liittyvät asioitten ajamiseen vanhojen ihmisten kannalta katsoen, 3) arvioida hankkeita/vanhojen tarpeet, 4) pohtia yhdessä uusia ratkaisuvaihtoehtoja ja 5) saada tutkimusraportti suosituksineen kirjana tai e-julkaisuna julkisuuteen.

Syksyllä 2018 oltiin tilanteessa, jossa ykkösvaiheen raportit keväältä on analysoitu ja etsitty ne ongelmat, joihin eri elämäntilanteissa olevat kotonaan asuvat vanhat ihmiset ovat joutuneet. Hankkeiden johtajat ovat kirjoittaneet artikkelinsa hankkeistaan ja nämä on lähetetty kansalaistutkijoiden arvioitaviksi. Tutkimuksessa ollaan vaiheessa 4) eli yhteisessä pohdinnassa siitä, miten asioitten ajaminen vanhojen ihmisten kannalta voitaisiin järjestää.

Vanhat ihmiset, mutta myös hankkeiden johtajat sekä muutama haastateltu vanhusasiantuntija, joka tarkkailee omaan ympäristöään, toimivat kansalaistutkijoina. Lintuhavainnoitsijat lähettävät biologisessa tutkimuksessa havaintonsa tutkijoille, jotka hoitavat analyysin siitä lähtien itse. Tässä tutkimuksessa kansalaistutkijat ovat läsnä koko ajan. Tutkimuksessa on piirteitä sekä oppivasta yhteisöstä että radikaalista muuttamispyrkimyksestä. Kansalaistutkijat joutuvat pohtimaan omaan tilannettaan sekä keinoja, joilla päästään eteenpäin yksilöllisellä ja yhteisöllisellä tasolla. Kansalaistutkijat ovat korkeakoulutettuja henkilöitä, jotta heillä on valmiuksia analyyttiseen tarkasteluun. Hankkeissa olleet asiantuntijakansalaistutkijat joutuvat miettimään oman hankkeensa relevanssia suhteessa kansalaisten ilmaisemiin ongelmiin. Yhdessä on tarkoitus pohtia eritasoisia keinoja.

Jo tässä vaiheessa on käynyt ilmi, että näillä koulutetuilla on suuriakin ongelmia selviytyä kamppailusta julkisen vallan palvelujärjestelmien ja asioinnin kanssa. Samoin ongelmia tuottaa digimaailman erittäin nopea muuttuminen. Kansalaisvelvollisuuksien täyttäminen tuottaa tuskaa, vaikka koulutuksensa perusteella näiden henkilöiden tulisi selviytyä vaivatta perustehtävistä. Minkälainen tilanne voikaan olla niiden kohdalla, joiden kulttuuriset, sosiaaliset ja taloudelliset valmiudet ovat heikot ja joiden terveys heikkenee koko ajan raihnaistumisen myötä? 


\section{ONKO KANSALAISTUTKIMUS TUTKIMUSTA?}

Kansalaistutkimuksella on samoja piirteitä kuin toimintatutkimuksella. Siinäkin tutkimuksen kohteena olevat ihmiset osallistuvat itse tutkittavien yhteiskunnallisen epäkohtien parantamiseen. Yhteiskuntatieteellinen kansalaistutkimus eroaa traditionaalisesta luonnontieteellisestä tutkimuksesta, joka on ollut empiirisen yhteiskuntatutkimuksen esikuva. Tämän esikuvan mallia toistetaan myös tutkimusraporteissa ja erityisesti nykyään "pakollisessa" julkaisemisessa kansainvälisissä yhteiskuntatieteellisissä aikakauslehdissä. Joka artikkelissa toistetaan rakenteellista kaavaa: tausta, teoreettiset lähtökohdat, aineisto, tutkimusmenetelmät, analyysi ja johtopäätökset. Tutkimus ymmärretään luonnontieteistä opitun kaavan mukaisena suorituksena.

Kansalaistutkimuksessakin on mukana tämä kaava mutta eri osat eivät erotu näin selkeästi. Esimerkkitutkimuksessa ne menevät sekaisin ja päällekkäin prosessin aikana. Ammattitutkijan tehtävä on pitää kokonaisuutta koossa, tehdä analyyseja ja keskustella osatuloksista eri vaiheissa kansalaistutkijoiden kanssa. Kansalaistutkijat voivat itsekin osallistua eri vaiheiden toteuttamiseen mutta yhteistyössä ammattitutkijan kanssa. Myös tulosten raportointia voidaan tehdä eri vaiheissa ja siihen voivat osallistua myös kansalaistutkijat. Tämä artikkeli on esimerkki raportoinnista, silloin kun tutkimus ei vielä ole valmis. Esimerkkitutkimuksen kansalaistutkijoiden tuotoksista on jo tässä vaiheessa kirjoitettu artikkeleita muun muassa eläkeläisjärjestöjen lehtiin, jotta asioiden ajamisen pohdintaa voitaisiin vauhdittaa. Kirjoittamiseen osallistuvat myös kansalais- tutkijat. Kansalaistutkijoiden kannalta tärkeintä on prosessin loppuosa, sen toiminta- ja osallistumisosa, yhteistuotanto ja -luominen: Mitä voidaan tehdä havaituille ongelmille?

Onko tällaisessa monipolvisessa prosessissa kysymys "oikeasta" tutkimuksesta vai vain yhteiskunnallisesta toiminnasta, vanhojen ihmisten asioiden ajamisen edistämisestä vapaaehtoistyönä? Kaikki osallistujat ovat esimerkkitutkimuksessa itsekin vanhoja. He ovat koulutettuja ja jotkut myös alan, käytännön ja/tai tutkimuksen asiantuntijoita. Tutkimustoiminnalle ominaisia piirteitä tämä prosessi sisältää kysyessään mistä asioitten ajamisessa vanhojen ihmisten osalta oikeasti on kysymys, miten kansalaistutkijat ja hankkeet tämän ymmärtävät ja mitä osatekijöitä siihen sisältyy. Sen sijaan tutkimuskriteerien kannalta on epäilyttävää, että kohdejoukkoa ei ole valittu minkään systematiikan mukaan vaan kansalaistutkijoiksi ovat valikoituneet tietyn ikäiset kotonaan asuvat koulutetut henkilöt, jotka ovat suostuneet tulemaan mukaan. Empiirisissä tutkimuksissakin on riskinsä, jos kyselyjen potentiaaliset vastaajat tai haastatteluihin osallistujat eivät osallistukaan ja osallistumisen aste jää alhaiseksi. Kansalaistutkimuksessa, joka on osallistumisprosessi, vanhoille ihmisille voi tapahtua kaikenlaista, kuten tässäkin tapauksessa jo puolen vuoden aikana sairauksien pahenemista, kuolemantapauksia ja hoitokotiin siirtymisiä. Vapaaehtoistoiminnan voimin tapahtuvassa työskentelyssä ei kansalaistutkija-aineisto voi olla kovin laaja, koska jatkuva raportointi ja yhteydenpito kaikkiin osallisiin voisi muodostua laajan aineiston kyseessä ollen raskaaksi. 
Kansalaistutkimuksissa on todettu, että noin kaksikymmentä prosenttia osallisista jaksaa olla aktiivisia loppuun asti. Lukuun ottamatta mainittuja poistumia esimerkkitutkimuksessa kaikki ovat vielä mukana, toiset innokkaammin ja toiset enemmän seuraillen sitä, mitä tapahtuu.

Varttuneiden tutkijoiden harjoitukseksi tämän tapainen kansalaistutkimus sopii mitä mainioimmin, väitöskirjantekijälle ehkä huonommin. Kansalaistutkimus on osa uudenlaista tieteellistä ajattelua, avointa tiedettä, jota myös EU on nyt edistämässä (Open innovation, open science, open to the world 2016; Recommendations of the OSPP on Citizen Science 2018).

\section{KirjallisuUs}

Asiakaspalvelun uusi toimintamalli - autetaan asiakasta digitaalisten palvelujen käytössä (AUTA) 2016-2017.Valtiovarainministeriö. https://vm.fi/auta-hanke Luettu 15.10.2018

Citizen Science at Universities: Trends, Guidelines and Recommendations (2016) League of European Research Universities. Advice Paper No. 20, October 2016. Belgium. https://www. leru.org/files/Citizen-Science-at-Universities-Trends-Guidelines-and-Recommendations-Full-paper.pdf Luettu 1.10.2018

Digituen toimintamalliehdotus (2017) AUTA-hankkeen projektiryhmän loppuraportti. Valtiovarainministeriö. https:// vm.fi/documents/10623/6581896/ AUTA + raportti.pdf/74d0c25efa 60-43c6-8856-c418faef9085/ AUTA+raportti.pdf.pdf Luettu 1.10.2018

Geoghegan, H. \& Dyke, A. \& Pateman, R. \& West, S. \& Everett, G. (2016) Understanding Motivations for Citizen Science. Final Report. UKEOF Natural Environ- ment Research Council. http://www. ukeof.org.uk/resources/citizen-scienceresources/MotivationsforCSREPORTFINALMay2016.pdf Luettu 1.10.2018

Grünbuch Citizen Science Strategie 2020 für Deutschland (2017) https://www. buergerschaffenwissen.de/sites/default/ files/assets/dokumente/gewiss-gruenbuch_citizen_science_strategie.pdf Luettu 10.7.2018

Manchester Institute for Collaborative Research on Ageing MICRA. The University of Manchester. https://www.micra. manchester.ac.uk/ Luettu 1.10.2018

Nesti, Giorgia (2018) Co-production for innovation: the urban living lab experience. Policy and Society 37 (3), 310-325. https://doi.org/10.1080/14494035.201 7.1374692

Open innovation, open science, open to the world (2016) A vision for $\mathrm{Eu}-$ rope. Brussels: European Commission. https://publications.europa.eu/en/publication-detail/-/publication/3213b3351cbc-11e6-ba9a-01aa75ed71a1 Luettu 1.10.2018

Recommendations of the OSPP on Citizen Science (2018). Citizen Science Working Group of the Open Science Policy Platform. European Commission. https://ec.europa.eu/research/openscience/pdf/citizen_science_recomendations.pdf Luettu $1 \overline{5} .10 .201 \overline{8}$

The European Citizen Science Association ESCA. https://ecsa.citizen-science.net/ Luettu 1.7.2018

West, Sarah \& Pateman, Rachel (2016) Recruiting and Retaining Participants in Citizen Science: What Can Be Learned from the Volunteering Literature? Citizen Science: Theory and Practice, 1 (2), 1-10. https://doi.org/10.5334/cstp.8

White Paper on Citizen Science (2015) European Commission. Futurium. https://ec.europa.eu/futurium/en/content/white-paper-citizen-science Luettu 10.7.2018 